\title{
計測変位に基づく地下空洞周辺地山に発生する塑性領域の推定法*

\author{
A METHOD FOR THE EVALUATION OF PLASTIC ZONE AROUND UNDERGROUND \\ OPENINGS BASED ON MEASURED DISPLACEMENTS
}

\author{
桜井春輔**・清 水則一***・松室圭介**** \\ By Shunsuke SAKURAI, Norikazu SHIMIZU and Keisuke MATSUMURO
}

\begin{abstract}
In this paper a method is proposed for evaluating the extent of plastic zones appearing around underground openings by using displacements measured during excavations. The elasto-plastic boundary is determined by comparing the maximum shear strain occuring around the openings with the critical shear strain of materials. Both the maximum and critical shear strains can be determined by a back analysis for measured displacements.

Computer simulations using the finite element method are carried out in order to prove this proposed method. The method does not require any elasto-plastic analysis, but an only ordinary elastic analysis is sufficient.
\end{abstract}

Keywords : back analysis, field measurements, plastic zone, underground openings

\section{1. まえがき}

地山の強度が低くかつ初期応力が大きい場合，すなわ ち，地山強度比が小さい場合，地下空洞周辺に塑性領域 が発生する.この塑性領域の範囲を推定することは, 空 洞の安定性の評価や掘削工法, 覆工厚さおよびロックボ ルトの長さ等を検討するうえで重要である.理論的には, 塑性領域は有限要素法等による力学解析を行うことに よって求めることができるが, 解析に必要な地山の力学 定数や初期応力等を当初設計の段階で, 精度よく求める ことは非常に困難である. したがって，解析によって得 られる塑性領域は必ずしも実際と一致しない. そこで, 現場において空洞掘削時にその挙動を計測し, その結果 から当初予測した塑性領域の妥当性を検討し, 必要に応 じて支保ならびに掘削方法の見直しを行う方法が考えら れる.

* 本論文の一部は, 第 6 回岩の力学国内シンポジウム ${ }^{14)}$ お よび5th Int. Conf. on Numerical Methods in Geomechanics $^{15)}$ において発表している.

** 正会員 工博, Ph. D. 神戸大学教授 工学部土木工学 科（ 7657 神戸市灌区六甲台町 1-1)

*** 正会員 工修 神戸大学助手 工学部 (同上)

**** 正会員 工修 日本道路公団（元神戸大学大学院工学研 究科学生)
現場計測の結果から塑性領域の大きさを推定する方法 としては, 変位等の計测結果から, まず地山の力学定数 (粘着力, 内部摩擦角など) を求め, 次にそれらを用い て弾塑性解析を行う方法が考えられる. 計測変位等から 地山の力学定数を求めることは通常の解析の逆の手順之 なることから逆解析とよばれている. 地下空洞を対象と した逆解析法はすでにいくつか提案されているが(1) 5), 弾塑性問題を対象にした逆解析は少ない. 非線形な力学 特性を有する地山を対象に, Gioda らは ${ }^{6)}$, MohrCoulomb の降伏規準に従う弾・完全塑性体を仮定して, 水室試験で得られる変位から, 岩盤の粘着力, 内部摩擦 角および初期応力を求める逆解析法を提案している. ま た, 荒井らは ${ }^{7)}$, 双曲線型応力ーひずみ関係式を用い, せん断強度を材料固有の定数 (Tresca 則) とし, さら に初期応力は既知と仮定して, トンネルの内空変位から 地山の変形・強度定数を逆解析によって求めている. 両 方法とも, 計算機の容量の制約や解の安定性の問題から 軸対称問題 (等方初期応力, 円形断面) に限定される.

ところで, 上記の方法はともに, 直接定式化法 ${ }^{8}$ に属 する逆解析法であり, 逆解析においては, 弾塑性解析 (非 線形解析）を多数繰り返し行わねばならない.したがっ て,これらの方法には高速多容量の計算機が必要となる. しかし, 計測結果を設計施工にフィードバックする目的 
で用いられる逆解析法は，現場において容易に実施でき るものでなければならない。

本論文においては,現場における適用性を第一に考え， 弾塑性解析を用いないで, 空洞掘削時の測定変位から地 山に発生する塑性領域を推定する逆解析手法を提案す る.

\section{2. 本研究の背景と目的}

地下空洞掘削時における現場計測は，一般に変位計測 が主である. 変位計測は, 応力等の測定と比べて, 比較 的容易に信頼度の高い計測結果を得ることができる．桜 井は，変位計測に基づく地下空洞の安定性の評価法を提 案した ${ }^{91}$. その方法は従来の応力を基礎とした評価法に 対し，ひずみを基礎としている点に特徴があり，測定変 位から地山のひずみ分布を求め，これをひずみで与えた 破壊規準値と比較して空洞の安定性を評価するもので “值接ひずみ評価法 (DSET)”と名づけられている. 测定変位からひずみ分布を求める方法については，計測 点が十分に多い場合, 変位-ひずみ関係から直接求める ことができるが, 計測点が限られている場合には,まず, 地山の力学定数を逆解析によって求め, その結果を用い てひずみ分布を計算する方法が提案されている ${ }^{3 / 101}$. そ して, その目的のため直接逆解析プログラム (DBAP) が開発された.

さらに, 桜井らは有限要素法による数値シミュレ一 ションから次のような結果を得た ${ }^{11)}$.すなわち，まず， 弾塑性有限要素解析によって得られる変位を“計測変位” と仮定して, 等質等方の弾性モデルに基づく逆解析を行 う之, 地山の見掛けの初期応力および弾性係数が求めら れる. そして，それらをインプットとして弾性解析を行 うと, 得られる地山の最大せん断ひずみの等高線の 1 つ は, 真の弾塑性境界と近似的に一致する.このことは, もし, 弾塑性境界における最大せん断ひずみの值を与え ることができれば，地山のひずみ分布から直接，塑性領 域が推定されることを意味している.

以上の背景から本研究では, 弾塑性境界上の最大せん 断ひずみの值を測定変位の逆解析から求める方法を検討 し，地山の最大せん断ひずみ分布から空洞周辺に生じる 塑性領域の推定方法を提案することを目的とする.

\section{3. 仮定}

地山に対し次の仮定を設ける.

(1) 地山は, Mohr-Coulomb の降伏規準に従う弾 · 完全塑性体とする.

(2) 地山の応力ーひずみ関係は，降伏前は等方の Hooke の法則に従い, 降伏後は非関連流れ則を用いて 表わされる.なお, 塑性ポテンシャル関数にはVon

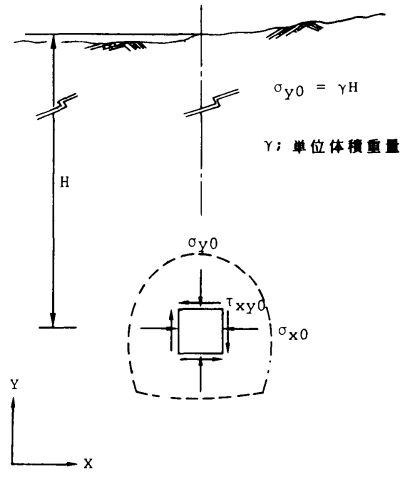

図一1 初期応力

Mises の関数 ${ }^{12)}$ 用いる.

(3) 空洞は, 地表面から十分深い位置に掘削され，地 山の初期応力は空洞掘削領域で一定とみなせる．また， 初期応力の鉛直成分は土被り圧に等しいとする（図一1 参照).

なお，本研究では二次元平面ひずみ状態を考える．ま た，圧縮応力を正とする

\section{4. 限界せん断ひずみ}

Mohr-Coulomb の降伏規準は次のように表わされる. $\sigma_{1}-\sigma_{3}=\left(\sigma_{1}+\sigma_{3}\right) \sin \phi+2 c \cos \phi$

ただし， $\sigma_{1}$ および $\sigma_{3}$ は最大および最小主応力，また， $c$ および $\phi$ はそれぞれ粘着力および内部摩擦角である. 地山の応力が単調に増加する場合, 弾塑性境界におい ては, Hooke の法則が成り立つので次式を得る.

$$
\sigma_{1}-\sigma_{3}=\frac{E}{1+\nu}\left(\varepsilon_{1}-\varepsilon_{3}\right)
$$

ただし， $\varepsilon_{1}$ および $\varepsilon_{3}$ は最大および最小主ひずみ，また，

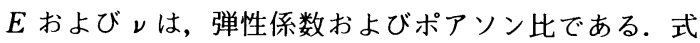

（2）を（1）に代入すると次式を得る.

$$
\varepsilon_{1}-\varepsilon_{3}=2 \frac{1+\nu}{E}(\bar{p} \sin \phi+c \cos \phi)
$$

ただし， $\bar{p}=\left(\sigma_{1}+\sigma_{3}\right) / 2$ である.

ここで，限界ひずみ ${ }^{9)} \varepsilon_{0}$ を導入する.

$\varepsilon_{0} \equiv \frac{\sigma_{c}}{E}=\frac{2 c \cos \phi}{E(1-\sin \phi)}$

ただし， $\sigma_{c}$ は一軸圧縮強度である。式 $(4)$ を式（3) に代入すれば次式を得る.

$$
\gamma_{c}=(1+\nu)\left\{2 \frac{\bar{p}}{E} \sin \phi+(1-\sin \phi) \varepsilon_{0}\right\}
$$

$\gamma_{c}$ は, 弾塑性境界における最大せん断ひずみであり, これを限界せん断ひずみと定義する.

式（5）において，限界ひずみ，ポアソン比および, 内部摩擦角は比較的容易に推定できる ${ }^{13)}$. したがって, 
限界せん断ひずみを求めるうえで， $E$ および $\bar{p}$ を゙の ようにして決定するかが問題となる.

次章では, $E$ および $\bar{p}$ の求め方, そして, 限界せん 断ひずみを用いて塑性領域を推定する方法を述べる.

\section{5. 塑性領域の推定}

\section{（1）初期応力が静水圧状態の地山に掘削される円形 空洞の場合}

a) 地山の弾性係数の決定法

まず, 地山を弾性体とみなし, 測定変位の逆解析から 弾性係数を求める(これを弾性逆解析とよぶ).この場合, もし実際に空洞周辺に塑性領域が発生していれば,ここ で得られた弾性係数は, 真の弾性係数ではなく見掛けの 弾性係数となる.この見掛けの弾性係数と真の弾性係数 の関係が見出せれば，弾性逆解析によって得た見掛けの 弾性係数から真の弾性係数を得ることができる．ここで は，見掛けの弾性係数と真の弾性係数之の関係を，次の ようにして求める.

図一2に示すように, 初期応力が静水圧状態にある地 山に, 円形空洞が掘削される場合，地山の半径方向変位 は次のように与えられる.

$$
\begin{aligned}
& u^{\rho}=\frac{1+\nu}{E}\left(p_{0} \sin \phi+c \cos \phi\right)\left(\frac{\lambda}{a}\right)^{2} \frac{a^{2}}{r} \\
& \frac{\lambda}{a}=\left\{(1-\sin \phi)\left(\frac{p_{0}}{c} \tan \phi+1\right)\right\}^{\frac{1-\sin \phi}{2} \sin \phi} . .
\end{aligned}
$$

ただし， $a$ は空洞半径， $\lambda$ は塑性領域の半径である。な お，簡単のために, 式 $(6)$ を誘導する過程において, 塑性領域の掘削による体積ひずみは無視している.

一方，弾性地山に掘削される円形空洞において地山の 半径方向変位は, 次のように求められる.

$$
u^{e}=\frac{1+\nu}{E} p_{0} \frac{a^{2}}{r}
$$

いま, 弾塑性地山を弾性地山とみなし, 逆解析を行う なら, 式（6）で表わされる変位を測定変位と考えて, 次式を得る.
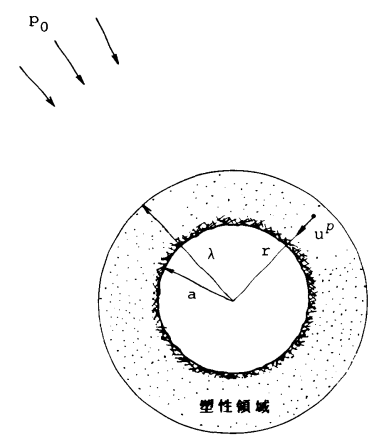

图一2 初期応力が静水圧状態の地山に 掘削された円形空洞 $u^{e}=u^{p}$

このとき, 式（８）における弾性係数およびポアソン比

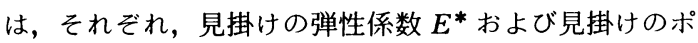
アソン比 $\nu^{*}$ となる. 式（4) および式（6)〜（8）を 考慮すると, 式 (9) から地山の真の弾性係数と見掛け の弾性係数との関係式は次式のように求められる.

$$
E=\frac{E^{*} \sin \phi}{\left\{\left(\frac{2 p_{0}}{\varepsilon_{0} E}-1\right) \sin \phi+1\right\}^{-\frac{1-\sin \phi}{\sin \phi}}-\frac{\varepsilon_{0} E^{*}}{2 p_{0}}(1-\sin \phi)}
$$

ただし，見掛けの弾性係数から真の弾性係数を求めると き，計算結果に及ぼすポアンン比の影響は小さいため， ここでは $\nu=\nu^{*}$ とおき式 (10) を誘導した。

見掛けの弾性係数 $E^{*}$ は, 変位計測結果から弾性逆解 析によって容易に求めることができる。したがって， $p_{0}$ に土被り圧を与え, 内部摩擦角 $\phi$ および限界ひずみ $\varepsilon_{0}$ を仮定すれば, 式 (10) 加真の弾性係数 $E$ を求める ことができる (付録参照).

b) 塑性領域

本問題（図一2参照）では，式（5）における $\bar{p}$ は, $\bar{p}=p_{0}$ (土被り圧）である. したがって，式（5）に， 式（10）から求められる真の弾性係数を代入すれば，限 界せん断ひずみ $\gamma_{c}$ が計算できる.

一方, 式 (8) と見掛けの弾性係数とから求められる 地山の最大せん断ひずみを $\gamma_{\max }$ とおくと， $\gamma_{\max }=\gamma_{c}$ を 満たす半径 $r_{0}$ の円周は弾塑性境界と一致することが容 易に示される.

\section{（2）初期応力および空洞形状が一般的な場合}

初期応力および空洞形状が一般的な場合には，前節の 方法を拡張して次のように考える。すなわち，

(1) まず，測定変位の弾性逆解析を行い，見掛けの弾 性係数を求める.

(2) 見掛けの弾性係数と真の弾性係数の関係式は，近 似的に式 (10) が成り立つとして, 見掛けの弾性係数を 式（10）に代入して真の弾性係数を求める.このとき, 内部摩擦角および限界ひずみは仮定する．また， $p_{0}$ に は弾性逆解析によって得た初期応力の最大主応力の值を 与えることにする.

(3) 限界せん断ひずみ $\gamma_{c}$ は式（5）に真の弾性係数 を代入し求める．ただし，ポアソン比は仮定する．また， $\bar{p}$ には弾性逆解析によって得た初期応力の最大主応力の 值を与える.

(4) 地山の最大せん断ひずみ $\gamma_{\max }$ の分布と限界せん 断ひずみ $\gamma_{c}$ とを比較し, $\gamma_{\max } \geqq \gamma_{c}$ となる領域を塑性領 域と推定する.

以上の方法の妥当性は次章で検証する. 


\section{6. 数值シミュレーション}

5. (2) で示した方法の妥当性を数值シミュレーショ ンによって検証する。

\section{（1） 数值シミュレーションの手順}

数值シミュレーションは, 以下の手順に従って行う.

手順(1) “测定変位”：3. で仮定した地山に掘削され た空洞に対し，通常の弾塑性解析を有限要素法によって 行う. その結果求められる要素節点の変位を “測定変位” とする.

手順(2) 弾性逆解析：手順(1)で与えられる“測定変位” を用いて弾性逆解析を行い, 見掛けの弾性係数を求める. 弾性逆解析には著者の一人が開発した直接逆解析プログ ラム $(\mathrm{DBAP})$ を用いる. すなわち, まず, DBAPによっ て“測定変位” から初期応力パラメーター $\left\{\bar{\sigma}_{0}\right\}=$ $\left\{\sigma_{x}^{0 *} / E^{*} \sigma_{y}^{0 *} / E^{*} \tau_{x y}^{0 *} / E^{*}\right\}^{T}$ を求める. ここに, $\sigma_{x}^{0 *}$, $\sigma_{y}^{0 *}$ および $\tau_{x y}^{0 *}$ は初期応力の各成分である.ただし, 地 山が弾性体でない限り,これらは見掛けの初期応力であ り，真の值と区別される.

次に， $\sigma_{y}^{0 *}$ に土被り圧を与えて，

$$
\sigma_{y}^{0 *}=\gamma H
$$

( $\gamma$ : 単位体積重量, $H:$ 土被り高さ)

$\sigma_{y}^{0 *} / E^{*}$ から見掛けの弾性係数 $E^{*}$ を, さらに他の初 期応力パラメーターから, 初期応力の残りの成分を求め る.

手順(3) 真の弾性係数亡限界せん断ひずみ：式 (10) に見掛けの弾性係数 $E^{*}$ を代入し, 内部摩擦角および限 界ひずみを仮定して, 真の弾性係数 $E$ を求める. 次に, $E$ を式 $(5)$ に代入し， $\gamma_{c}$ を求める. このとき, $p_{0}=\bar{p}$ $=\sigma_{1}^{0 *}\left(\sigma_{1}^{0 *}:\right.$ DBAP によって得た初期応力の最大主応 力）とする.

手順(4) 地山の最大せん断ひずみ：手順(2)で求めた初 期応力パラメーターから通常の弾性有限要素法を用いて 地山のひずみを求める.この計算で求められるひずみは 掘削によって生じたひずみ増分 $\{\Delta \varepsilon\}=\left\{\Delta \varepsilon_{x} \quad \Delta \varepsilon_{y} \quad \Delta \gamma_{x y}\right\}^{T}$ である.したがって, 全ひずみは次式で求められる.

$$
\{\varepsilon\}=\left\{\varepsilon_{0}\right\}+\{\Delta \varepsilon\}
$$

ただし， $\left\{\varepsilon_{0}\right\}$ は空洞掘削以前の初期ひずみを表わし，次 式を用いて求める.なお，ここでは水平方向の初期応力 はすべての方向に等しいとした.

$$
\left\{\varepsilon_{0}\right\}=\left\{\begin{array}{c}
\varepsilon_{x}^{0} \\
\varepsilon_{y}^{0} \\
\gamma_{x y}^{0}
\end{array}\right\}=\left[\begin{array}{ccc}
1-\nu & -\nu & 0 \\
-2 \nu & 1 & 0 \\
0 & 0 & 2(1+\nu)
\end{array}\right]\left\{\bar{\sigma}_{0}\right\} \cdots \cdot
$$

したがって，全ひずみに対する最大せん断ひずみは，次 式によって計算される.

$$
\gamma_{\max }=\sqrt{\left\{\left(\varepsilon_{x}^{0}+\Delta \varepsilon_{x}\right)-\left(\varepsilon_{y}^{0}+\Delta \varepsilon_{y}\right)\right\}^{2}+\left(\gamma_{x y}^{0}+\Delta \gamma_{x y}\right)^{2}} \cdots(14)
$$

手順(5) 塑性領域 : 手順(3)および手順(4)で求めた $\gamma_{c}$
と $\gamma_{\max }$ から, $\gamma_{\max } \geqq \gamma_{c}$ の範囲を塑性領域とし，これを 手順(1)で求めた真の塑性領域とを比較することにより提 案手法の妥当性を確かめる.

（2）数值シミュレーション結果

数値シミュレーションに用いた地山の力学定数を表一 1 に示す.この場合, 限界ひずみは $\varepsilon_{0}=0.87 \%$ となる. 以下に，手順(1)（5)に従い種々の形状の空洞に対して 行ったシミュレーションの結果について述べる.

\section{表一1 地山の力学定数}

\begin{tabular}{cccc}
\hline$E$ & $v$ & $c$ & $\phi$ \\
\hline $1.96 \times 10^{2} \mathrm{MPa}$ & 0.3 & $4.90 \times 10^{-1} \mathrm{MPa}$ & $30^{\circ}$ \\
\hline
\end{tabular}

a) 馬蹄形空洞 (case 1(a), (b))

[case 1(a)]

初期応力は， $\sigma_{x}^{0}=\sigma_{y}^{0}=4.90 \mathrm{MPa}, \tau_{x y}^{0}=0$ とする（図 一3).また，図一4 はここで用いた有限要素分割図であ る.まず，表一1 の値を用い手順(1)によって “測定変位” を求める. 次に手順(2)に従い，DBAPによって弾性逆 解析を行うと $(\nu=0.3$ と仮定 $)$, 初期応力パラメーター は次のように求まる.

$$
\left\{\bar{\sigma}_{0}\right\}=\left\{\begin{array}{l}
\sigma_{x}^{0 *} / E^{*} \\
\sigma_{y}^{0 *} / E^{*} \\
\tau_{x y}^{0 *} / E^{*}
\end{array}\right\}=\left\{\begin{array}{l}
5.18 \times 10^{-2} \\
4.58 \times 10^{-2} \\
0.00
\end{array}\right\}
$$

手順(3において，まず，土被り圧は既知と仮定してい るので, $\sigma_{y}^{0 *}=4.90 \mathrm{MPa}$ を与え, 見掛けの弾性係数 $E^{*}$ $=1.07 \times 10^{2} \mathrm{MPa}$ を得る. $E^{*}$ を式 (10) に代入し， $\phi$ $=30^{\circ}, \varepsilon_{0}=0.87 \%$ (いずれも “測定変位”を求める解 析で用いた正解値) を与えると, 真の弾性係数として $E=2.16 \times 10^{2} \mathrm{MPa}$ を得る. 一方, 逆解析によって求め た初期応力の最大主応力は $\sigma_{1}^{0 *}=5.54 \mathrm{MPa}$ であるので, $p_{0}=\bar{p}=5.54 \mathrm{MPa}$ とおく. したがって，限界せん断ひ ずみは, 式 $(5)$ から $\gamma_{c}=3.90 \%$ となる.

図一 5 に，推定される塑性領域，すなわち， $\gamma_{\max } \geqq \gamma_{c}$ の領域と, 真の塑性領域 (手順(1)において弾塑性有限要 素法によって求めたもの) を示す．両者を比較すると，

$$
4.90 \mathrm{MPa} \Omega
$$

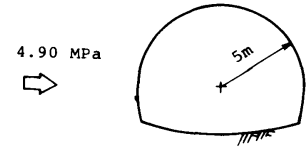

ப

図一3 馬蹄形空洞 (case 1(a)) 


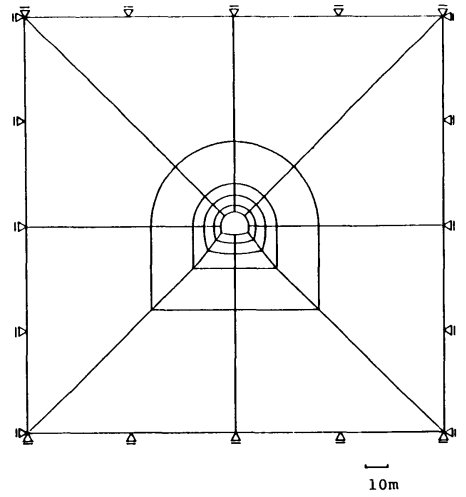

図一4 有限要来分割図（馬蹄形空洞の場合）

よい一致を示していることがわかる．表一2( 1 ) に逆解 析の結果得た諸値を示す.なお, 粘着力は, 式 (4)に よって求めた.

[case $1(b)]$

初期応力は, $\sigma_{x}^{0}=2.45 \mathrm{MPa}, \sigma_{y}^{0}=3.43 \mathrm{MPa}, \tau_{x y}^{0}=$ $-0.85 \mathrm{MPa}$ (最大主応力 $\sigma_{1}^{0}=3.92 \mathrm{MPa}$, 最小主応力 $\sigma_{3}^{0}=1.96 \mathrm{MPa}$, 最大主応力方向と鉛直軸のなす角 $\theta=$ $-30^{\circ}$ ) とする (図一6参照)。逆解析の結果得た諸値を 表一2（２）に示す. 図一7は，逆解析によって求めた塑 性領域と真の塑性領域を比較したものである.このケ一

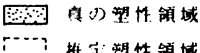

$\left(\gamma_{C}=3.908\right)$

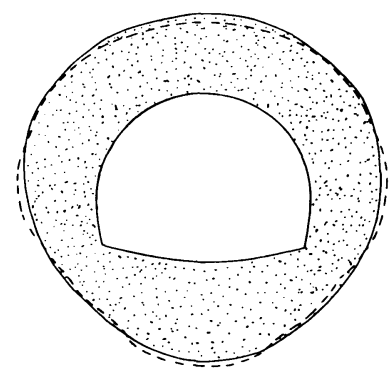

図一5 馬蹄形空洞周辺に生じる望性領域（case 1(a)）
スも塑性領域は精度よく求められることがわかる.

b) 半円形空洞 (case 2)

図一8に示す半円形空洞に対し，case 1(b) と同じ初 期応力を用いシミュレーションを行う。表一2( 3 ) に逆 解析結果を示す. 推定される塑性領域を図一9に示す. この図から明らかなように，底盤中央付近において逆解 析によって得た塑性領域は，真の塑性領域と幾分異なる が，おおむねよい精度で一致している。

c) 方形空洞 (case 3,4)

図一10 および 11 に示す正方形空洞（case 3) および 長方形空洞 (case 4) に対してシミュレーションを行う. 表一2(4) および（５）にそれぞれの逆解析結果を示す.

正方形の場合, 塑性領域は比較的精度よく推定されて いる（図-12）。しかし，長方形空洞では側壁において，
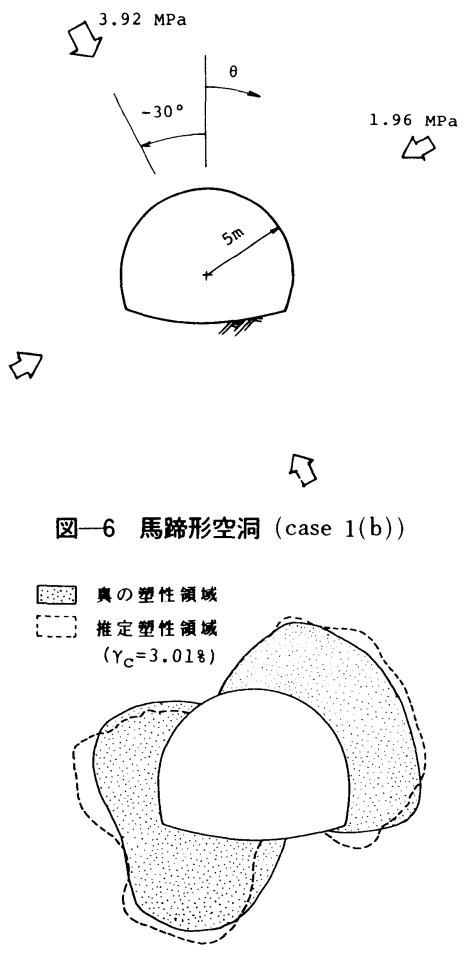

図一7馬蹄形空洞周辺に生じる塑性領域（case 1(b)）

\begin{tabular}{|c|c|c|c|c|c|c|c|c|c|c|c|}
\hline & \multicolumn{10}{|c|}{ 表一2 逆解析結果 } \\
\hline & & \multicolumn{2}{|c|}{ (1) } & \multicolumn{2}{|c|}{ (2) } & \multicolumn{2}{|c|}{ (3) } & \multicolumn{2}{|c|}{ (4) } & \multicolumn{2}{|c|}{ (5) } \\
\hline & & \multicolumn{2}{|c|}{ case $1(a)$} & \multicolumn{2}{|c|}{ case 1 (b) } & \multicolumn{2}{|c|}{ case 2} & \multicolumn{2}{|c|}{ case 3} & \multicolumn{2}{|c|}{ case 4} \\
\hline & & 逆解析 & 真の值 & 逆析 & 真の值 & 逆解析 & 真の值 & 逆解析 & 貝の值 & 逆繁折 & 直の㑲 \\
\hline$\sigma_{0}^{1}$ & $(\mathrm{MPa})$ & 5.54 & 4.90 & 3.96 & 3.92 & 4.21 & 3.92 & 3.80 & 3.92 & 4.00 & 3.92 \\
\hline$\sigma_{0}^{3}$ & (MPa) & 4.90 & 4.90 & 2.25 & 1.96 & 2.43 & 1.96 & 2.12 & 1.96 & 2.47 & 1.96 \\
\hline$\theta$ & (deg.) & 90.0 & I & -33.7 & -30 & -41.3 & -30 & -28.0 & -30 & 52.4 & 60 \\
\hline $\mathrm{E}^{*}$ & $\left(x 10^{2} \mathrm{MPa}\right)$ & 1.07 & - & 1.28 & - & 1.49 & - & 1.28 & - & 1.41 & - \\
\hline & $\left(x 10^{2} \mathrm{MPa}\right)$ & 2.16 & 1.96 & 2.10 & 1.96 & 2.37 & 1.96 & 2.08 & 1.96 & 2.24 & 1.96 \\
\hline$\gamma_{c}$ & $(8)$ & 3.90 & - & 3.01 & - & 2.88 & - & 2.94 & - & 2.88 & - \\
\hline & ( $\times 10^{-1}$ Mpa) & 5.40 & 4.90 & 5.26 & 4.90 & 5.92 & 4.90 & 5.19 & 4.90 & 5.61 & 4.90 \\
\hline
\end{tabular}




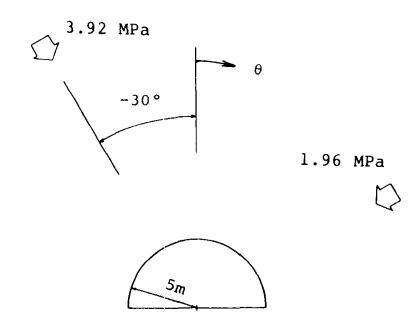

Q
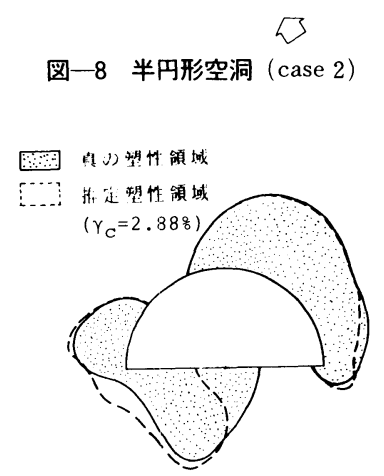

図一9 半円形空洞周辺に生じる塑性領域（case 2)

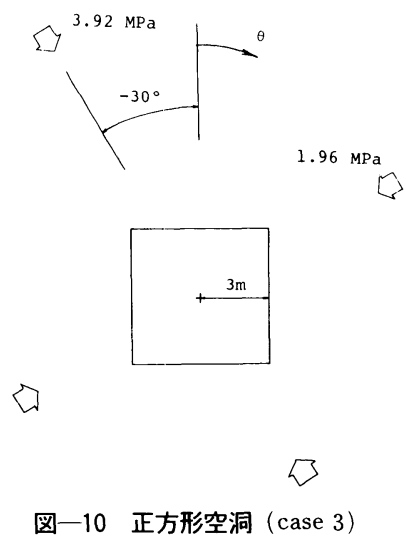

真の塑性領域と比較して, 若干小さく塑性領域が求めら れている (図一13 参照).これは, 式 (10) は円形空洞 に対して導いたものであるため, 空洞の形状が円形と異 なる度合が大きくなるに従って, 式 (10) の有効性が失 われるからと考えられる. しかし, 側壁を除いた地点で は, 真の塑性領域とおおむねよい一致を示している.

\section{7. 提案手法}

数值シミュレーションの結果に基づき, 以下に示す塑 性領域の推定法を提案する.

(1) 空洞掘削時に測定される地中変位や内空変位をイ
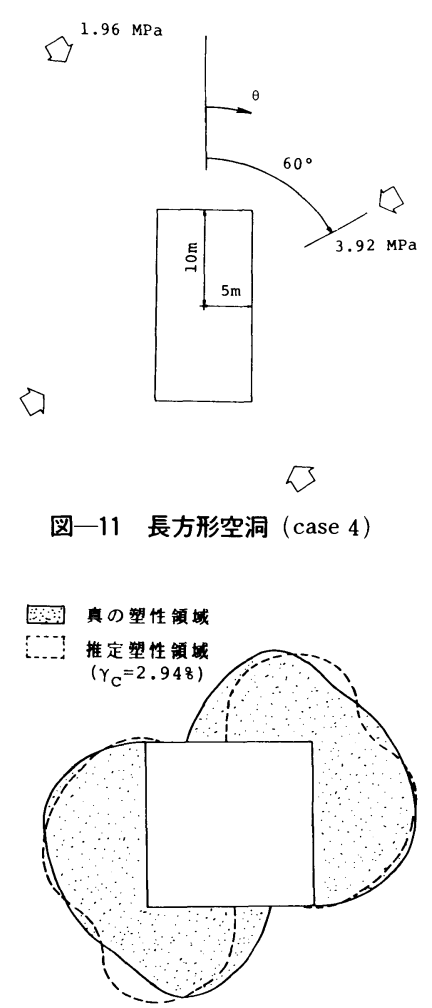

図一12 正方形空洞周辺に生じる塑性領域（case 3)

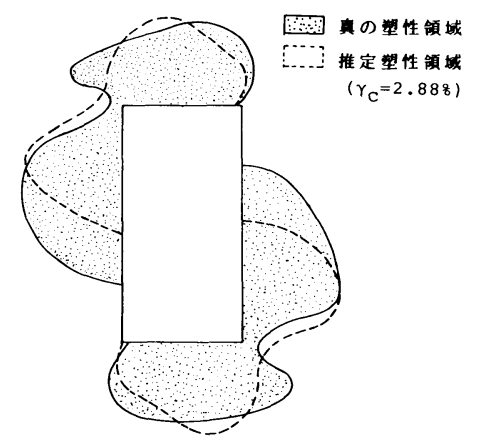

図一13 長方形空洞周辺に生じる望性領域（case 4)

ンプットデータとして, 直接逆解析プログラム (DBAP) を用い弾性逆解析を行い, 見掛けの弾性係数 $E^{*}$ および 初期応力の最大主応力 $\sigma_{1}^{0 *}$ を求める.ただし, DBAP では地山のポアソン比は仮定する. また, 初期応力の鉛 直方向成分は土被り圧と等しいとする.

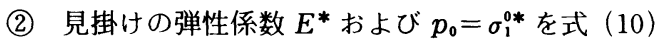
に代入し, 真の弾性係数 $E$ を求める. ただし, 地山の 内部摩擦角 $\phi$ および限界ひずみ $\varepsilon_{0}$ は仮定する. さらに, $E$ および $\bar{p}=\sigma_{1}^{0 *}$ を式（5）に代入し, 限界せん断ひず み $\gamma_{c}$ を求める.

(3) DBAPによって求めた見掛けの弾性係数と初期 


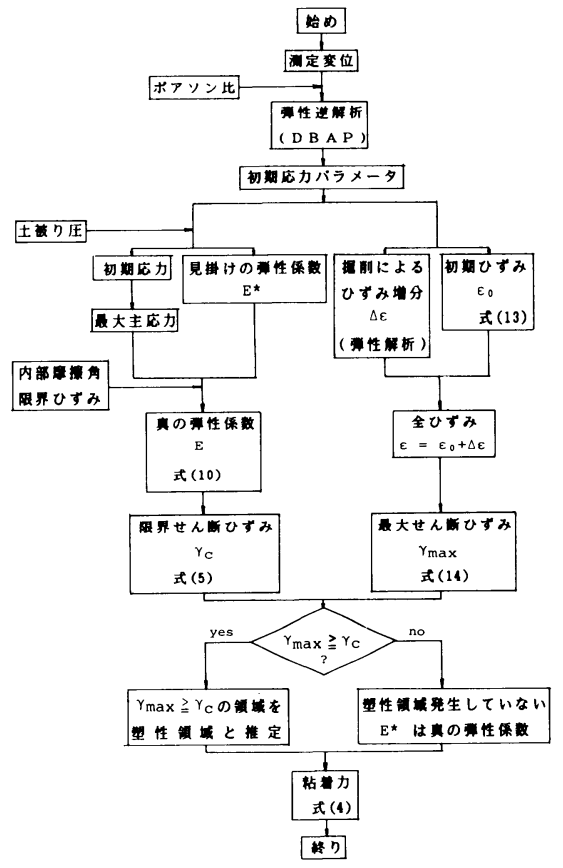

図一14提案手法

态力を用い，通常の弾性解析を行い掘削によって生じた 地山のひずみ増分を求める. 一方, 式 (13) から初期ひ ずみを求め,これにひずみ増分を加えた全ひずみを用い, 式（14）から最大せん断ひずみ $\gamma_{\text {max }}$ を求める.

(4) $\gamma_{\max } \geqq \gamma_{c}$ の範囲を塑性領域と推定する. 必要なら ば, 式 (4) から地山の粘着力を求める.もし, 地山の いかなる点においても $\gamma_{\max }<\gamma_{c}$ の場合，塑性領域は発 生していないと判断する.このとき, 見掛けの弾性係数 は真の弾性係数となる.

図一14に提案手法のフローチャートを示す。

\section{8. むす.び}

本論文では, 地下空洞掘削時に測定される変位の逆解 析結果から,地山に発生する塑性領域を推定する方法を, 数值シミュレーションの結果を踏まえて提案した．この 方法は，著者の一人がすでに開発した直接逆解析プログ ラム (DBAP) に基づき, 弾塑性解析を行うことなく, 測定変位のみから直接, 塑性領域を推定することができ る特徵を有する．本方法では地山のポアソン比，内部摩 擦角および限界ひずみは仮定しているが，これらは現場 において比較的容易に推定できることがわかってい る $^{13)}$.また, 提案手法はパーソナルコンピューターによっ て稼働し，計測結果を直ちに解析できるため，本手法の 現場への適用性は高いと考えられる。
付 録

式（10）は Newton-Raphson 法を用いて解くことが できる.

まず，式 $(\mathrm{A} \cdot 1)$ において，初期值を $E_{0}=E^{*}$ とおく. 次に, $E_{i}=E_{t-1}+\Delta E_{i}$ が収束するまで計算を繰り返す。 通常, 4 5 回で収束する.

$$
\Delta E_{i}=-\frac{K_{i}^{\frac{\sin \phi}{1-\sin \phi}}-\left(\frac{2 p_{0}}{\varepsilon_{0} E_{i-1}}-1\right) \sin \phi-1}{\frac{\sin \phi}{1-\sin \phi} L_{i} K_{i}^{\frac{2}{2} \sin \phi-1}+\frac{2 p_{0} \sin \phi}{\varepsilon_{0} E_{i-1}^{2}}}
$$

$$
K_{i}=\frac{E_{i-1}}{B+A E_{i-1}}, \quad L_{i}=\frac{B}{\left(B+A E_{i-1}\right)^{2}}
$$

$A=\frac{\varepsilon_{0} E^{*}}{2 p_{0}}(1-\sin \phi), B=E^{*} \sin \phi$

\section{参考文 献}

1) Kovari, K., Amstad, Ch. and Fritz, P. : Integrated Measuring Technique for Rock Pressure Determination, Proc. Int. Sympo. on Field Measurements in Rock Mechanics, Zürich, pp. 289 316, 1977.

2) Gioda, G. and Jurina, L. : Numerical Identification of Soil-Structure Interaction Pressures, Int. J. Numer. Anal. Methods in Geomechanics, Vol.5, No.1, pp. 33 $56,1981$.

3）桜井春輔・武内邦文：トンネル掘削時における変位計測 結果の逆解析法, 土木学会論文報告集, 第 337 号, pp. $137 \sim 145,1983$.

4）久武勝保：トンネルにおける三次元逆解析法の開発, 土 木学会論文集, 第 376 号 $/$ III-6, pp. 259 265, 1986.

5）桜井春輔・清水則一・壹内達也：地下空洞における計測 変位の境界要素法による三次元逆解析法, 土木学会論文 集, 第 382 号 /III-7, pp. 55 61，1987.

6) Gioda, G. and Maier, G. : Direct Search Solution of an Inverse Problem in Elastoplasticity: Identification of Cohesion, Friction Angle and In-Situ Stress by Pressure Tunnel Tests, Int. J. Numer. Methods Eng., Vol. 15, pp. 1823 1848, 1980.

7）荒井克彦・片瀬貴文：トンネル内空変位計測に基づく地 盤変形・強度定数の推定, 土質工学会論文集, Vol.24, No. 2, pp. 171 179, 1984.

8) Cividini, A., Jurina, L. and Gioda, G. : Some Aspects of "Characterization" Problems in Geomechanics, Int. J. Rock Mech. Min. Sci. \& Geomech. Abstr., Vol. 18, pp. 487 503, 1981.

9）桜井春輔：トンネル工事における変位計測結果の評価法, 土木学会論文報告集，第 317 号，pp. 93 100，1982.

10）桜井春輔・進士正人：マイクロコンピューターによる地 下空洞掘削時の安定性の評価, 土木学会論文集, 第 358 号 /III-3, pp. 37 46, 1985.

11) Sakurai, S. and Abe, S. : A Design Approach to Dimensioning Underground Openings, Proc. 3rd Int. 
Conf. Numer. Methods in Geomechanics, Aachen, pp. $649 \sim 661,1979$.

12) Zienkiewicz, O.C. : The Finite Element Method, 3rd Ed., New York, McGraw-Hill, 1977.

13) Sakurai, S. : Displacement Measurements Associated with the Design of Underground Openings, Proc. Int. Sympo. on Field Measurements in Geomechanics, Zürich, Vol.2, pp. 1163 1178, 1983.

14）桜井春輔・清水則一・松室圭介：現場計測結果に基づく
トンネル周辺の塑性領域の推定法, 第 6 回岩の力学国内 シンポジウム講演論文集, pp. 263〜268, 1984.

15) Sakurai, S., Shimizu, N. and Matsumuro, K. : Evaluation of Plastic Zone Around Underground Openings by Means of Displacement Measurements, Proc. 5th Int. Conf. on Numerical Methods in Geomechanics, Nagoya, Vol. 1, pp. 111 118, 1985.

(1987.8.24 - 受付) 